\title{
Biophysical sustainability, process-based monitoring and forest ecosystem management decision support systems
}

\author{
by J.P. Kimmins ${ }^{1,2}$, R.S. Rempel ${ }^{3}$, C.V.J. Welham¹, B. Seely ${ }^{1}$ and K.C.J. Van Rees ${ }^{4}$
}

\begin{abstract}
Sustainability is a key concept in resource management and environmental issues, but implementation is fraught with difficulty due to lack of agreement as to what it means. Because of the ubiquity of disturbance, ecosystem sustainability inevitably involves change. We define stand-level biophysical sustainability as non-declining patterns of change over at least three cycles of disturbance, and landscape-level sustainability as a shifting mosaic of non-declining stand change, the overall character of which remains within acceptable limits over time. Simple empirical assessment (i.e., monitoring) of this concept of sustainability is generally not practical in forestry because of the long time and large spatial scales involved. Adaptive management (AM), another key resource management concept, involves monitoring to assess the consequences of management actions. It requires forecasts of expected change in sustainably managed, post-disturbance ecosystems against which to assess monitoring data. Without these forecasts, which constitute temporal fingerprints of sustainable change, short-term monitoring data cannot be used reliably as a basis from which to assess longer-term sustainability. A comprehensive monitoring system to address biophysical sustainability locally and at the landscape scale for a large management unit over a rotation-length time scale would involve the key elements of ecosystem structure and function and the effects thereon of management and climate change. This would be prohibitively expensive and demanding of human resources and the results would not be available until the end of the rotation. A strategy that honours the intent of AM is an intimate linkage between predictive monitoring and process-based ecosystem management decision support systems-ecosystem process-based monitoring - the emphasis of which is on temporal patterns of indicator change rather than comparisons between static indicators and audits of current ecosystem conditions (the certification approach). It involves a combination of monitoring and ecosystem management modeling that reduces the long-term cost of monitoring and increases the utility of the data collected for the assessment of sustainability and for the design of policy and adaptive practice in forestry.
\end{abstract}

Key words: prediction, process-based monitoring, sustainability, forest ecosystems, biophysical indicators, temporal fingerprints, adaptive management, ecosystem management models

\section{RÉSUMÉ}

La durabilité est un concept clé de l'aménagement des ressources et des enjeux environnementaux, mais son implantation présente de multiples difficultés du fait de l'absence d'entente sur sa signification. Compte tenu de l'ubiquité liée aux perturbations, la durabilité d'un écosystème implique obligatoirement des changements. Nous définissons la durabilité biophysique au niveau du peuplement comme étant des patrons non successifs de changement au cours d'au moins trois cycles de perturbations, et la durabilité au niveau de l'écosystème comme étant une mosaique progressive de changements non successifs de peuplements, le tout s'opérant au cours d'une période de temps acceptable. L'évaluation empirique simple (par ex., le suivi) de ce concept de durabilité n'est habituellement pas réalisable en foresterie à cause des longues périodes de temps et des importantes dimensions spatiales impliquées. L'aménagement adaptatif (AM) un autre concept clé d'aménagement des ressources, implique un suivi afin d'évaluer les conséquences des interventions d'aménagement. Il nécessite des prévisions portant sur le changement prévu dans les écosystèmes aménagés de façon durable suite à une perturbation à partir des quels on peut effectuer le suivi. Sans ces prévisions, qui constituent l'empreinte digitale temporelle du changement durable, les données de suivi à court terme ne peuvent être utilisées de façon fiable en tant que base pour pouvoir évaluer la durabilité à plus long terme. Un système de suivi global permettant de d'effectuer un suivi de la durabilité biophysique à l'échelle locale et au niveau de l'écosystème pour une importante unité d'aménagement au cours d'une révolution impliquerait les éléments essentiels de la structure de l'écosystème ainsi que leurs fonctions et effets sur l'aménagement et les changements climatiques. Cela entraînerait des dépenses prohibitives en terme de ressources humaines et les résultats ne seraient pas disponibles avant la fin de la révolution. Une stratégie qui tient compte des intentions de l'AM tisse des liens serrés entre le suivi prédictif et les systèmes d'aide à la décision reposant sur l'aménagement de l'écosystème-un suivi effectué à partir de l'écosystème-l'emphase étant sur les patrons temporels des indicateurs de changement plutôt que la comparaison entre les indicateurs statiques et la vérification des conditions actuelles de l'écosystème (l'approche de la certification). Cela comporte une combinaison de suivi et de représentation de l'aménagement de l'écosystème qui réduit les coûts à long terme du suivi et accroît l'utilité des données recueillies pour l'évaluation de la durabilité et pour l'élaboration de directives et de pratiques adaptatives en foresterie.

Mots clés : prédiction, suivi du processus, durabilité, écosystèmes forestiers, indicateurs biophysiques, empreintes digitales temporelles, aménagement adaptatif, modèles d'aménagement de l'écosystème

\footnotetext{
${ }^{1}$ Department of Forest Sciences, Faculty of Forestry, University of B.C., Vancouver, British Columbia V6T 1 Z2.

${ }^{2}$ Corresponding author. E-mail: Hamish.Kimmins@ubc.ca

${ }^{3}$ Centre for Northern Forest Ecosystem Research, Lakehead University, Thunder Bay, Ontario P7B 5E1.

${ }^{4}$ Department of Soil Science, 51 Campus Drive, University of Saskatchewan, Saskatoon, Saskatchewan S7N 5A8.
} 


\section{Introduction}

We define forestry as the art (skill), practice, science, and business of managing forest stands and forested landscapes to maintain an ecologically sustainable and socially desirable balance of values and environmental services.

Aside from an early period of exploitative harvesting, forestry has always been concerned with sustaining a defined set of desired values. The traditional focus on maintaining a constant flow of harvestable products has been widely replaced by concern over sustainability of the entire ecological system-its many components, processes, environmental services and values for human society (e.g., Thomas 1995, Messier and Kneeshaw 1999, Rauscher 1999, Kimmins 2002a). Sustainability has been the subject of many international processes and initiatives (e.g., Bruntland 1987, UNCED 1992, Salim and Ullsten 1999, Annan 2000) and is the ultimate objective of forest certification (e.g., Cashore et al. 2005, www.CertificationWatch.org). In Canada, we have a National Centre of Excellence in Sustainable Forest Management (Burton et al. 2003) and the Canadian Council of Forest Ministers Criteria and Indicators of sustainable forestry (CCFM 1997; http://www.ccfm.org/index_e.php). Yet confusion remains and debate continues over both the definition of sustainability and how it might be achieved in practice (Oliver et al. 2000, Nemetz 2004, Kimmins 2007a). This is particularly true with respect to the biophysical aspects of sustainable forest management (SFM) - commonly referred to as the ecological component of the three-legged stool of SFM, with economics and social being the other two components.

Frequently confused with the Victorian concept of the "balance of nature", biophysical sustainability is often interpreted to mean constancy, equilibrium and lack of change in species, structure or function at the stand level, overlooking the fact that stand-level ecosystem attributes inevitably change over time in both unmanaged and managed forests. In ecosystems that are undergoing sustainable disturbance regimes, this results in non-declining patterns of change in a variety of stand-level ecosystem characteristics over several cycles of disturbance. Short-term declines in certain ecosystem attributes are frequently misinterpreted as a threat to biodiversity and other ecosystem values, especially if human-caused. However, when considered in the context of a landscape mosaic such small-scale change may be of minor significance, could increase large-scale diversity and may even be necessary for the long-term sustainability of regional populations.

For many people, the fundamental objective of the biophysical aspect of SFM is the maintenance of biodiversityitself a complex and widely misunderstood concept (Kimmins 1997, 1999). There is a widespread feeling that sustaining forest biodiversity means maintaining forests in an "old growth" condition characterized by late or climax seral stages; that the complete, albeit temporary, loss of forest cover at the stand level leading to earlier seral communities or stand structures must be avoided. There has also been a strong emphasis on stand structural elements such as dead trees (snags) and the presence of large decomposing logs (coarse or large woody debris) because these are clearly important from a biodiversity perspective (Franklin et al. 1997, 2002; Lindenmayer and Franklin 2003). However, achieving desired levels of biodiversity (regardless of how it is measured) across the landscape involves management to support the full sequence of biotic communities that constitute the "ecologi- cal play" (Fig. 1). Only if all acts (i.e., seral stages) of the play are represented in the landscape are the habitat needs of all the ecological actors (i.e., species) likely to be provided (Kimmins 2005, 2007a).

Adequate soil condition is a prerequisite for the maintenance of forest ecosystem productivity (Kimmins 1977, Johnson 1994, Olsson et al. 1996, Nisbet et al. 1997, Schoenholtz et al. 2000, Powers et al. 2004). Yet this component has received relatively less attention in the general debate over sustainability and is commonly ignored in forest growth models used in forest planning (but see, for example, Morris et al. 1997, Bhatti et al. 1998, Wei et al. 2003).Clearly, biophysical sustainability involves many forest attributes, all of which should be considered in a broader ecosystem context of SFM, including the social and economic components (Kneeshaw et al. 2000).

Given the inevitability of change in ecosystem condition over time (Attiwill 1994, papers in Perera et al. 2004), how can we assess whether we are achieving sustainability? One approach is to use knowledge accumulated over several disturbance cycles to evaluate sustainability. However, we lack experience of managing forests under conditions of humaninduced climate change and of management systems other than those that typify historical practices. How, then, do we evaluate sustainability for a changing and uncertain future?

Here we address some of the biophysical aspects of sustainability in forestry, consider the requirement for forecasts of patterns of change in stand- and landscape-level forest attributes to support an adaptive management approach, discuss the type of predictive systems that are necessary to make such forecasts, and propose an approach to monitoring sustainability-process-based ecosystem monitoring - that is practical and contributes to the goals of SFM.

\section{Dimensions of Biophysical Sustainability - The Ecolog- ical Underpinnings of Stewardship and Ethical Forestry} Biophysical aspects of sustainability involve maintaining the key processes of production ecology, first at the primary (plant) production level, and then at the consumer (animal) and decomposer (microbial) levels. Key determinants of primary production within the framework set by climate include leaf area, foliar photosynthetic efficiency and carbon allocation, all of which are influenced by light, nutrients and water. Consideration of the processes that determine moisture and nutrient availability, and processes of competition for light, nutrients and moisture, are clearly fundamental to any assessment of the sustainability of primary production and its harvestable component. Biomass accumulation reflects net photosynthetic production minus losses to litterfall and plant mortality, both of which result from a combination of physical disturbance factors (e.g., wind, fire), production allocation (to ephemeral or perennial biomass structures) and biotic interactions (parasites, pathogens, competition). Secondary production is determined by a complex of food availability, habitat requirements, diseases, natural enemies and climate. Because these are the determinants of future production, monitoring to assess sustainability should in theory address them explicitly. However, the practical difficulties in assessing animal populations generally leads to a dependence on coarse-filter indicators of sustainability, which in turn requires consideration of the factors that determine habitat suitability and supply—primary production, stand dynamics and ecological succession. 


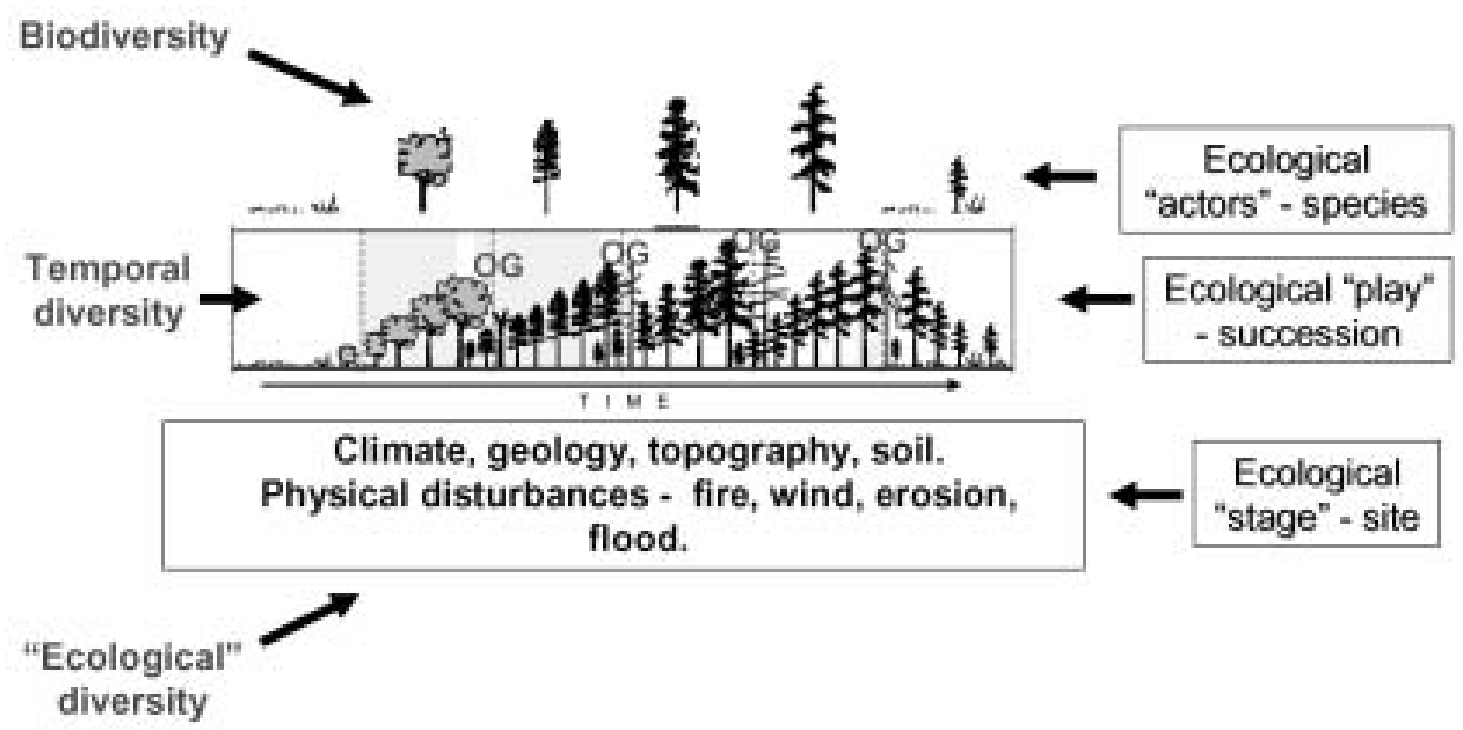

Fig. 1. Diagrammatic representation of the concept of "ecological theater." Only one or a few plant species ("actors") are shown for each "act" (seral stage and its biotic community) of the ecological "play" (the successional sequence of communities/seral stages following stand-replacing disturbance), whereas in reality there will be many species ("actors") "on stage" in each "act." This diagram implies that the "script" or "storyline" for the "ecological play" is constant and will be repeated exactly following ecosystem disturbance. In reality, it can vary according to different types, severities, spatial scales and timing of disturbances, differences in ecosystem character and condition, and the resultant variation in the processes of ecosystem development. "Biodiversity" refers to the diversity of genes, species and biotic communities. The physical diversity of the landscape and physical disturbances constitutes "ecological diversity." This is the environmental framework within which biodiversity develops; it is not in itself biodiversity, contrary to the many definitions that claim that it is. Temporal diversity is the change in biotic and local physical conditions over time. Note that "old growth"-a phase of stand dynamics—develops at the end of each "act" (seral stage) of the "ecological play" (after Kimmins 2007b).

These determinants are usually considered at the stand or local ecosystem level. However, stands are continually changing as they undergo disturbance and successional development and sustainability should thus be assessed in terms of non-declining patterns of change. If sustainability is to be considered as a continual supply of resource values and ecosystem conditions, assessment must be made at the landscape scale. This should be in terms of a shifting mosaic of stands undergoing non-declining patterns of change, the overall character of which remains relatively constant across the landscape over time.The importance of spatial and temporal scales in assessing sustainability is now discussed in more detail:

\section{Spatial scale}

Assessment of sustainability requires a consideration of spatial scale. A 100-ha clearcut in a 100-ha woodlot would not provide an uninterrupted supply of a variety of ecosystem values from that woodlot. In contrast, annual harvests of 100-ha patches distributed across a 100 000-ha landscape would not threaten the continuing supply of the many values provided by that landscape, nor the meta-populations of disturbance-adapted organisms that populate the area. In fact, this disturbance regime will likely serve to maintain or increase the overall diversity of the landscape by sustaining all acts of the ecological play. It could, however, have dire consequences for any organisms whose range is restricted to a given 100-ha patchsomething that is unlikely in temperate and northern forests.
The impact of harvesting on soil productivity is a standlevel issue but its effect is cumulative across the landscape. Persistent or temporary loss of productive forest area (e.g., through the construction of roads and landings) is therefore meaningful only at the landscape scale. Harvesting impacts on hydrology must be considered at multiple spatial scales. Riparian retention areas (buffer strips) provide for local inputs of structure to streams, while forest removal must be quantified over scales that span several orders of watershed in order to infer impacts of management on peak flow events and total stream flow. Quantifying the impacts of forest management activities on other regional and global cycles, including carbon sequestration and fluxes of other "greenhouse" gases, must similarly be made at both stand and landscape scales.

\section{Temporal scale}

Assessments of forest management are frequently based on "snapshot" evaluations-static pictures or audits at a single point in time. Yet the biophysical sustainability of forest ecosystems can only be truly assessed within the context of patterns of temporal change. For example, one of the most important features of biodiversity is its temporal diversitythe variation in all other biodiversity measures over time. Temporal diversity cannot be assessed reliably by snapshot evaluations (cf. Rempel et al. 2004).

Disturbance (for examples of its definition, see Kimmins 2004) at any given spatial scale will generally have its greatest 

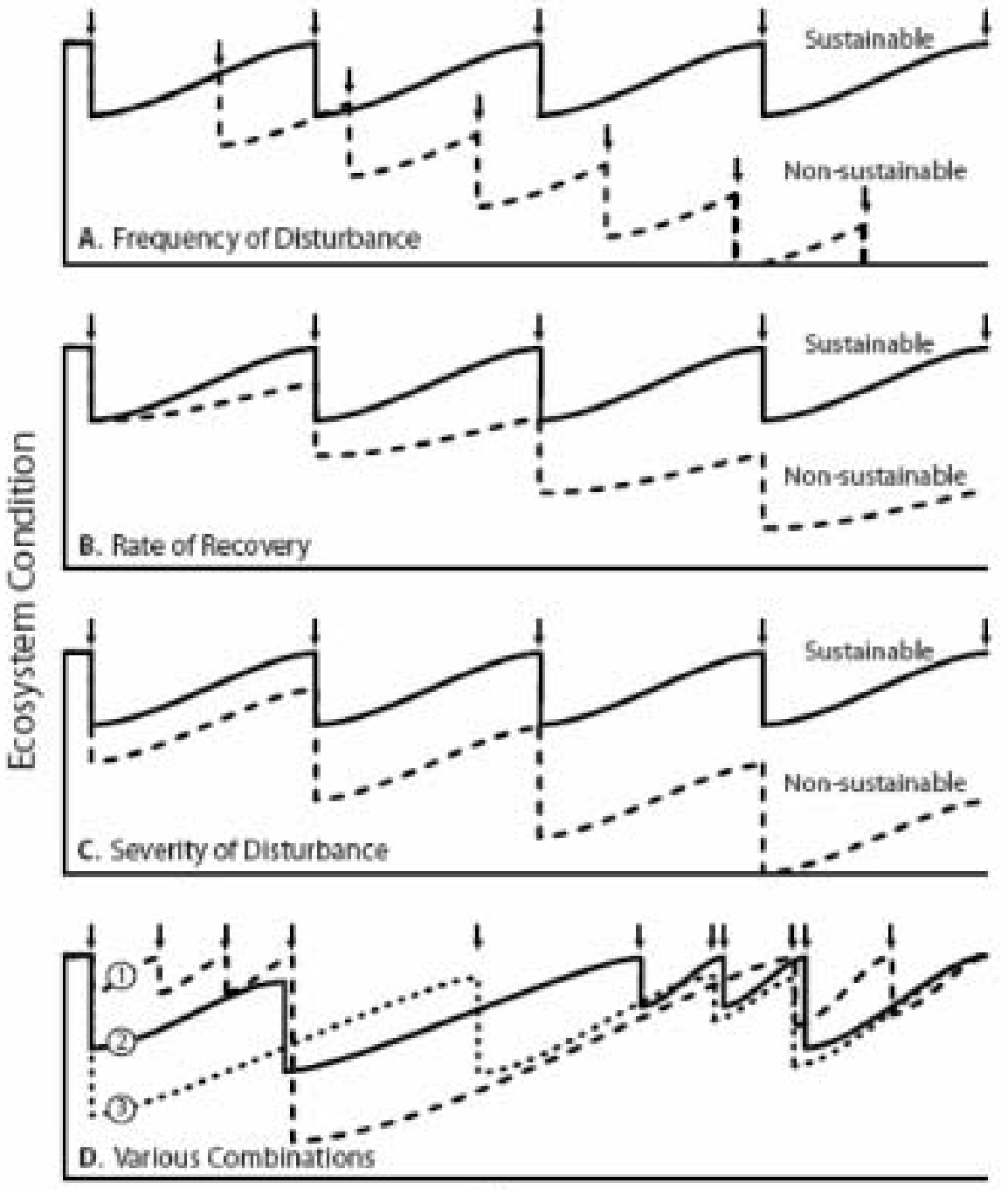

Time

Fig. 2. Biophysical sustainability. Sustainability is a function of the frequency of disturbance (A), the rate of recovery (B) and the severity of disturbance (C). A wide variety of different disturbance frequencies, severities and rates of recovery can be sustainable as long as the time scale of evaluation is appropriate. At different time scales, the results of disturbance may be deemed either sustainable or unsustainable.

effect on ecosystem form and function immediately following its occurrence. The effect tends to lessen with time as vegetation recovers and processes of autogenic succession cause the area to transition towards its pre-disturbance condition or to some new and different forest condition. At a medium spatial scale of disturbance (the local stand level, for example), the time required for recovery may be relatively short and consequently an ecosystem can tolerate this level of disturbance at a relatively high frequency without any long-term downward trend in condition (Fig. 2A). As the relative size of the area and/or the degree of physical/biotic community alteration increases, the rate of recovery may be slower, thus reducing the sustainable frequency of a particular type of disturbance event (i.e., that frequency which will result in a non-declining pattern of change; Fig. 2B). In general, increases in the severity of ecosystem disturbance require longer recovery periods
(Fig. 2C). This may be because ecosystem processes have been slowed, or simply because the ecosystem has been regressed further back in the successional sequence but without any reduction in the rate of successional recovery. Rates of postdisturbance ecosystem development will vary with ecosystem type and condition.

As a consequence of these ideas, it is not reasonable to conclude that moderate or even severe disturbance is any less sustainable than low-severity disturbance unless both the frequency of disturbance and rate of ecosystem recovery are considered.

Combining spatial and temporal scales in the concept of ecological rotation

Biophysical sustainability in forestry is determined by the interaction between disturbance severity (scale and degree of 
ecosystem change), disturbance frequency, and the rate of ecosystem recovery (Fig. 2D). The interactions between these three factors are captured by the concept of ecological rotation (Kimmins 1974): the time for overall ecosystem condition or for any particular ecosystem variable to return to predisturbance condition or to some new desired condition following a given type and severity of disturbance.

A management practice or natural disturbance regime (severity, extent and frequency) that is sustainable for one ecosystem value, component or process may not be sustainable for other values, components or processes. Different values or ecosystem services have different ecological rotations, which in turn vary between different types of forest ecosystem. As a consequence, uncritical application of the precau-

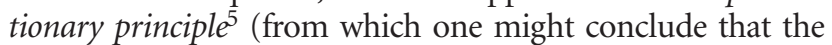
ecosystem should be managed according to the needs of the species or value with the longest ecological rotation) may fail to sustain the full range of desired species and ecosystem values. This suggests that there is not likely to be a single correct management system and disturbance regime that can be applied repeatedly everywhere across a forested landscape. For example, neither repeated and widespread clearcutting nor repeated and widespread partial harvesting is likely to provide the diversity of ecosystem conditions necessary to supply the values and services society desires today. Fig. 3 illustrates three different stand-level ecosystem patterns of change created by repeated management regimes that vary in frequency and severity of harvest disturbance; two involving clearcutting and one a partial harvest regime. A fourth regime that applies a variable management system over time to produce a temporal sequence of different species, values and ecosystem conditions is also shown. Maintaining any particular condition or narrow range of conditions for long periods by repeating the same disturbance regime may not be biologically sustainable as it can result in the build-up of diseases and pests or undesirable soil conditions. This can be true for both early seral and late seral forests. The fourth regime (Fig. 3 line 4) would ensure that the greatest range of values is sustained over the long run, but involves continual change in specific values in any one stand; it does not sustain any particular condition over time in that stand. Some might judge this fourth regime less sustainable than the other three, yet the opposite may be true especially if sustaining any one seral stage or condition leads to increasing risk of insect, disease, fire and/or soil problems.

\section{Potential vs. realized sustainability}

Claims that forests are being managed sustainably are often based on measures of potential rather than actual sustainability. Kneeshaw et al. (2000) make a similar distinction in classifying indicators of SFM as either prescriptive (potential) or evaluative (actual). For example, although maintenance of a non-declining pattern of change in soil fertility is a prerequi-

\footnotetext{
${ }^{5}$ The precautionary principle concerns actions undertaken to forestall potentially irreversible or unacceptable change even though the risk of that change occurring is uncertain. A widely used description of the precautionary principle is found in Article 15 of the Rio declaration of 1992: "Where there are threats of serious or irreversible damage, lack of full scientific certainty shall not be used as a reason for postponing cost-effective measures to prevent environmental degradation" (UNCED 1992).
}

site for sustaining forest productivity, this does not in itself guarantee sustained levels of tree production. If disease, herbivores, competition from non-crop species and/or other factors prevent the development of maximum leaf area of desired tree species, growth may decline even if soil fertility is sustained; alternatively, these factors may exacerbate growth loss caused by soil fertility decline (Bi et al. 2006, Royo and Carson 2006). Similarly, preservation of key habitat elements does not guarantee that populations of target wildlife species will be sustained if predation, hunting, disease, and/or other mortality agents act as independent limiting factors. Rempel et al. (2004) conclude that the best course of action for maintaining and assessing the sustainability of forest management practices is to use both potential and actual measures/indicators within a complimentary system.

\section{Sustainability, Adaptive Management and Monitoring} It is one thing to commit to sustainability in forest management; it is another to know if one is successful in achieving it. The need to make informed "midcourse" corrections to resource management strategies (often developed from sparse observational data) to avoid long-term damage to resource stocks led to development of the concept of adaptive management (Walters 1986). Adaptive management, in its purest form, is based on the premise that past experience may not be a reliable basis for policy and management decisions and that every new management action constitutes a potential experiment. As in all good experimental designs, there should be a variety of different treatments (different methods of management), the results of which are carefully monitored, and the outcomes of the treatments compared.

Evidence that farming or fishing is being conducted sustainably can be demonstrated empirically over relatively short time periods (a few years or a decade) because detrimental effects can be ascertained relatively quickly. In contrast, the inherently long time scale of change characteristic of northern temperate and boreal forest ecosystems suggests that monitoring may not detect important consequences of management actions for at least several decades. Sometimes, meaningful empirical evidence of sustainability of forest management can require a century or more of measurement at landscape as well as at stand spatial scales, depending on the value in question. The shape of a trend line is not well described by plotting only two points-at least three are required. This suggests that biophysical sustainability in forestry requires a time scale of at least three cycles of disturbance (e.g., three timber crop rotations in even-aged stands and landscapes) or three average life spans in uneven-aged forests. This highlights the necessity of using potential measures to augment actual measures of sustainability through the use of both process-based, ecosystem-level simulation models and empirically derived habitat models specifically designed to address issues of biophysical sustainability (Seely et al. 1999, 2004; Guisan and Zimmermann 2000; Messier et al. 2003).

If monitoring shows a change in ecosystem values, conditions, components or processes, how does one evaluate whether this is sustainable or one should switch to a management practice that does not result in such a change? Adaptive management addresses this question and the problem of long time scales by requiring that monitoring be conducted in conjunction with forecasts of the patterns of change in the conditions or values of interest that would be expected in an 


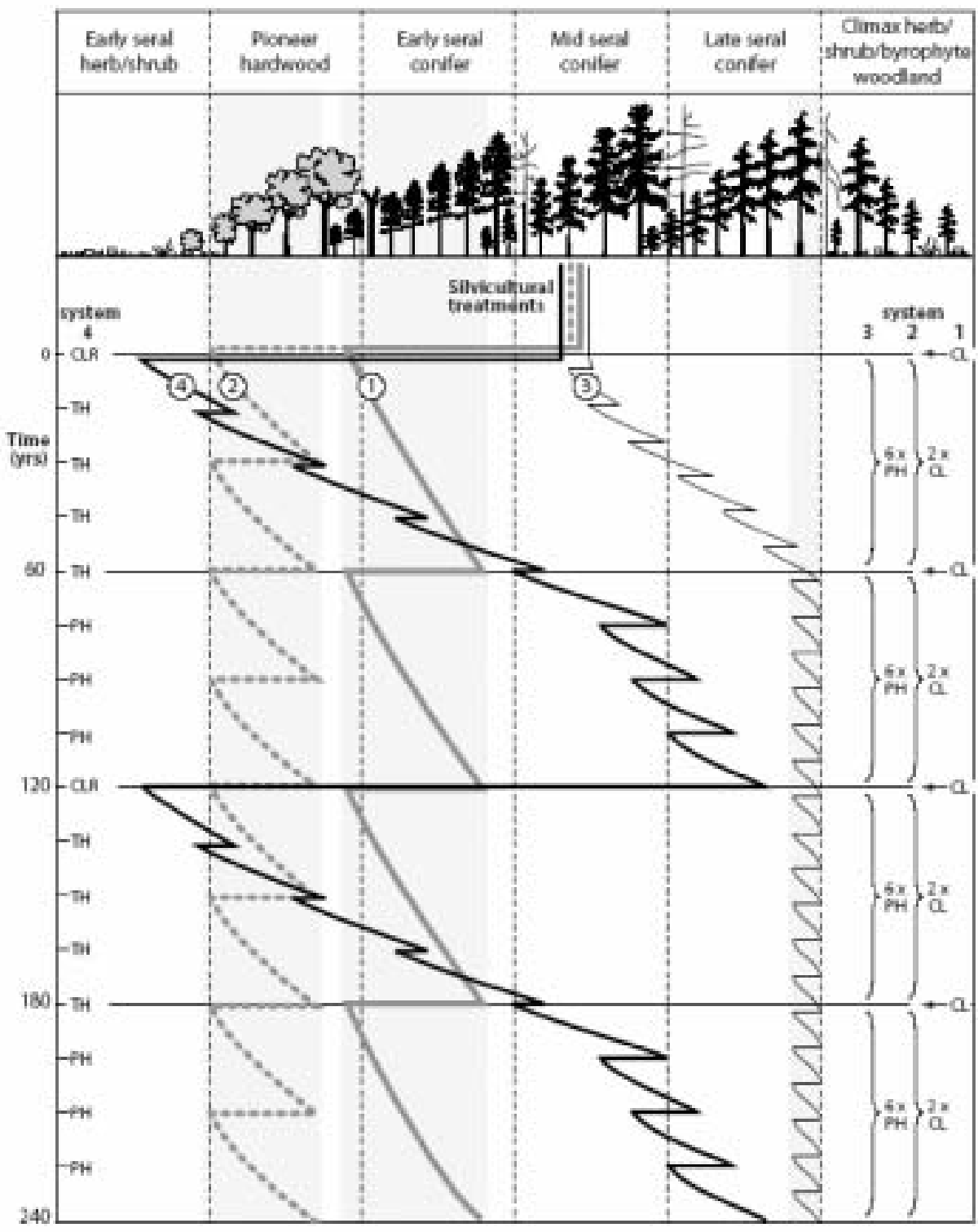

Fig. 3. Three different ecosystem conditions (lines 1-3) sustained by particular frequencies and severities of management-induced ecosystem disturbance applied repeatedly, compared with a sequence of conditions over time produced by changing the management regime periodically (line 4) (Kimmins 2004). The legend at the right of the diagram refers to clearcutting (CL) and partial harvesting $(\mathrm{PH})$ in systems 1-3. System 1 is a repeated 60-year rotation. System 2 is a repeated 30-year rotation with site preparation, and system 3 is repeated partial harvests at 10-year intervals. System 4 is a series of different silvicultural systems: an initial clearcut with vigorous site preparation, four commercial thinnings at 15-year intervals, three partial harvests at 15-year intervals, and a final clearcut at year 120. The sustainability of lines 1-3 suggested in the diagram ignores the problems of insects and diseases that can build up in some types of forest ecosystem if the same seral stage is repeated on the same area over long periods.

ecosystem that is being managed sustainably. It involves forecasts of expected changes in "healthy", "normally" functioning, post-disturbance ecosystems against which to assess monitoring data (Kimmins 1996). Such forecasts constitute temporal fingerprints of sustainable change (Kimmins 1990a, b; 2002b) in which short-term monitoring data can be used reliably to assess long-term sustainability. Since experience alone generally does not provide for reliable forecasts in a changing and uncertain future, adaptive management and results-based forestry will not be effective without the creation of such temporal fingerprints.

\section{Forecasting Tools for Adaptive Management and the Creation of "Temporal Fingerprints"}

In the past, forests were often managed for a single or small group of values - e.g., game species, timber, or fuel wood. Societal attitudes and values have changed, and most forests today are or should be managed for a variety of ecosystem 
values, conditions and services. When the objectives of management were narrowly focused, decision support tools were generally limited to the ecosystem component of interest; they were not combined into ecosystem-level decision support systems. With today's requirement for sustainability of a wide variety of values and ecological services, decision support systems for adaptive and sustainable forest management need to address multiple values and span multiple scales. This can be accomplished by applying stand-level, ecosystem management models and linking them to landscape-level models. The stand-level models should address issues of soil, climate and water as well as sustainability of biological production, and should contribute to analyses of wildlife habitat and measures of biodiversity. They should be capable of addressing the effects of both natural and management-induced disturbance on ecosystem form and function (Kimmins 1990c, Messier et al. 2003, Seely et al. 2004). Because forestry is first and foremost about people's needs, desires and beliefs (Westoby 1987), such decision support systems should also address social values - economics, employment, wealth creation, and environmental services - that are directly related to the biophysical characteristics of forests.

The case has been made that forest growth models used for sustainability assessment and adaptive management should include a simulation of key processes that are expected to change in the future (e.g., climate change impacts on forest growth processes, and the consequences of alternative silviculture systems for soil fertility, competition for resources between crop and non-crop plants, and pests and diseases; Korzukhin et al. 1996, Johnsen et al. 2001, Landsberg 2003). However, this need must be balanced against issues of model complexity, accuracy of predictions, and the relative feasibility of applying such tools (cf. Zeide 2003). One approach is to combine experience and understanding in "hybrid" models that link knowledge of key processes (e.g., photosynthesis and carbon allocation) with field measurements of the results of these processes (e.g., growth and biomass accumulation and turnover) such that estimates of the processes rates can be made without the need for extensive and expensive field measurements or estimates. Some examples of models using this and other hybrid approaches to projecting forest growth include are PNETII (Aber et al. 1995), 3PG (Landsberg and Waring 1997), FORECAST (Kimmins et al. 1999) and TRIPLEX (Peng et al. 2002). For a catalogue of models that are currently available and used in the Sustainable Forest Management Network in Canada, see Duchesneau (2005).

\section{Different Types of Monitoring and Linkage to Ecosystem- Level Modeling}

There are many different types of monitoring activities (see Mulder et al. 1999 and Holthausen et al. 2005 for thorough reviews). Here we define five categories and explore their relationship to ecosystem management modeling. For each of these categories we present approximate synonyms that have appeared in the literature.

Context monitoring (Baseline, Reference, and Background monitoring) refers to monitoring of ecosystems without specific reference to particular management actions. It is descriptive and inductive, and generally conducted in long-term unmanaged sites (parks, reserves, or migration monitoring stations). Context monitoring establishes reference conditions and process rates, including natural range of variability, but provides little basis for prediction under conditions for which we have no experience. If conducted for long enough, the results can provide background data with which to evaluate the effect on ecosystems of change due to management activities or climate.

Compliance monitoring (Implementation and Prescriptive monitoring) is used to determine if actions that were required or voluntarily prescribed were indeed implemented. It is often important to establish whether a planned management action actually occurred, and then to evaluate whether it created the intended effect. This type of monitoring often requires spatial inventory and information systems, and may utilize specialized sampling and analysis procedures for postharvest inventories. As with context monitoring it is descriptive and inductive and therefore of limited value for making the predictions needed in management planning.

Targeted monitoring (Census and Inventory monitoring) is designed to satisfy a special need, such as monitoring population trends of a specific game species or an animal community in a specific area with respect to specific management actions. Monitoring determines: (a) allowable harvest levels, and/or (b) whether previous harvest levels were too high or too low. This category often uses specialized inventory methods, such as helicopter surveys in moose inventories and waterfowl census.

Statistical monitoring (Cause-effect, Validation, and Retrospective monitoring) establishes correlative relationships between structure and function, action and response, and stressors and effects. These relationships can form the basis for predictions of responses, including threshold breakpoints between action (e.g., change in forest structure) and response (e.g., change in ecosystem state). Statistical monitoring requires specialized research methods, including judicious selection of sample plots, and typically uses design-based (e.g., random) sampling or model-based (e.g., sentinel) sampling to establish research plots. A tight linkage between statistical monitoring and research provides critical direction and focus to the research program, and ensures alignment of research with management information needs. However, because the monitoring is descriptive and inductive, the relationships identified are only valid for the conditions under which they were measured. Statistical monitoring establishes patterns of association through empirical relationships but does not identify their underlying "causal" mechanisms. Lacking any explicit representation of processes that determine the relationships, the products of statistical monitoring are not valid as predictors of future conditions under altered environmental conditions (e.g., climate, soils, biotic interactions).

Predictive monitoring (Effectiveness, Anticipatory, Refinement, and Prospective monitoring) has generally applied the quantitative models developed through statistical monitoring/ research to establish expected responses of individual values with respect to changes in management actions (stressors). It links research to management and is the payoff for the costly investments in statistical monitoring/research. Predictive monitoring has been used to evaluate the effectiveness of alternative forest management actions before they are implemented. The sample design is generally not random, but rather based on predictive outcomes, e.g., areas with expected high versus low response, or areas where inflection points on non-linear responses are expected to occur. The focus is on evaluative indicators. 
As noted above, the limitation of statistical monitoring, and therefore of predictive monitoring based thereon, is that it really constitutes "rear-view mirror driving." It is based on relationships between dependant variables (ecosystem condition, process rates) and past levels of independent variables (stressors such as climate, management or naturally-caused ecosystem disturbance) that existed over the period for which the relationship(s) was (were) established. If the future conditions (management, climate, soils, biotic conditions) remain the same, these relationships constitute valid predictors of subsequent ecosystem conditions. If they change significantly, however, the relationships are not valid predictors. As explained below, we believe that what is needed is processbased predictive monitoring, based on ecosystem-level, process based models.

\section{Process-Based Monitoring: The Linkage of Predic- tive Monitoring to Ecosystem Management Models}

Monitoring for sustainability in forestry can be a complex and potentially expensive proposition when it involves extensive lists of predictive and evaluative indicators for many different values (e.g., Rempel et al. 2004). The following are some of the perceived short-comings of conventional monitoring approaches:

- The temporal dimensions of change in temperate and boreal forest regions are such that empirical assessments of sustainability require lengthy periods of monitoring, over which climate is expected to change and, if history is any guide, forest management practices will undergo further evolution. As a consequence, by the time a meaningful empirical record of outcomes of management has been established, the information may have become an anachronism and a new empirical record will need to be assembled.

- Monitoring in the absence of predictive modeling may serve conservation and biodiversity concerns poorly. Where there is a risk of persistent species extirpations or even extinctions, we cannot rely purely on empirical monitoring. By the time we derive warning signals from such monitoring, species may already be at risk and it may not be possible to reverse the trend. For example, clearcutting old forests in the past generally left considerable legacies of large woody debris (LWD). This material provided terrestrial and aquatic habitat for a range of species that often persisted into the second managed rotation. However, much of this legacy will be depleted by the third or fourth rotation unless specific action is taken to ensure its renewal (e.g., through the use of variable retention systems). The point is that by the time monitoring reveals the lack of ecosystem structure its restoration may take too long to prevent the loss of species or other values that depend on it. Modeling can reveal the risks of such shortages in sufficient time to ensure appropriate management action.

- As with un-synthesized disciplinary research, independent monitoring of individual ecosystem structures and processes provides a poor guide for the development of effective management practices and policy at the stand or landscape level (Kimmins et al. 2005). Rather, assessments should be based on deviations between monitoring results and temporal fingerprints of desired and sustainable ecosystem variation based on ecosystem-level process models. The distinction between predictive monitoring of individual values outside of the integrating context of an ecosystem model and a truly ecosystem-level approach lies at the heart of the fundamental difference between true ecosystem management and the currently popular "ecosystem-based" management.(Kimmins 2007b). It is a question of whether we continue to manage and monitor individual structures, processes and values separately, or manage and monitor the ecosystem that provides these using a system that can accommodate change.

Given these shortcomings, there is a significant risk that monitoring will not be done effectively or at all; neither government agencies nor industry will have the budget or human resources to collect the necessary data. There is also the problem that government regulatory agencies may not have the resources to analyze and interpret the monitoring data, thereby limiting feedback from monitoring to management and policy-the adaptive part of AM. These and the other shortcomings of conventional approaches to the monitoring of sustainability in forestry discussed above can be addressed by process-based monitoring (PBM) at the ecosystem level (Fig. 4). The emphasis of PBM is the development and calibration (using monitoring and other data) of an ecosystemlevel, process-based prediction system. With this approach, "temporal fingerprints" of expected ecosystem change can be established that become the baseline against which data from context, compliance and other forms of monitoring are compared. PBM thus involves a combination of monitoring and ecosystem management modeling that reduces the long-term cost of monitoring and increases the utility of the data collected for assessing sustainability of multiple values.

PBM involves two distinct phases:

Phase I is conducted specifically to develop, calibrate and test (by comparison of model forecasts with monitored ecosystem consequences of "natural" or managementinduced disturbance regimes) new, or to calibrate and test existing process-based, ecosystem-level predictive systems, , and then to use them to explore which combinations of disturbance severity, frequency and natural or managementassisted ecosystem recovery are sustainable over various temporal and spatial scales. Rather than simply collecting data on individual indicators of sustainability, the focus is on defining mechanistic relationships between ecosystem processes and structures and ecosystem conditions/values of interest, and how these relationships are affected by management and natural disturbance processes.

The phase I exercise consists of two parts. In part 1, monitoring data collection is designed to calibrate the predictive relationships within the integrated ecosystem management modeling framework. Part 2 of Phase I involves collecting further data to provide an independent test of these relationships and of the predictive power of the PBM monitoring system; this establishes the level of accuracy and reliability of the decision support system.

Phase I of PBM is closer to applied research than to most other categories of monitoring. It will be somewhat more expensive and demanding than other types of monitoring, but this will be more than offset by reduced on-going monitoring costs and increased effectiveness of the monitoring activity (in Phase II; see below). Data collection in Phase I serves the dual purpose of relatively standard environmental monitoring and the development and testing of ecosystemlevel predictive tools and systems. The decision support sys- 


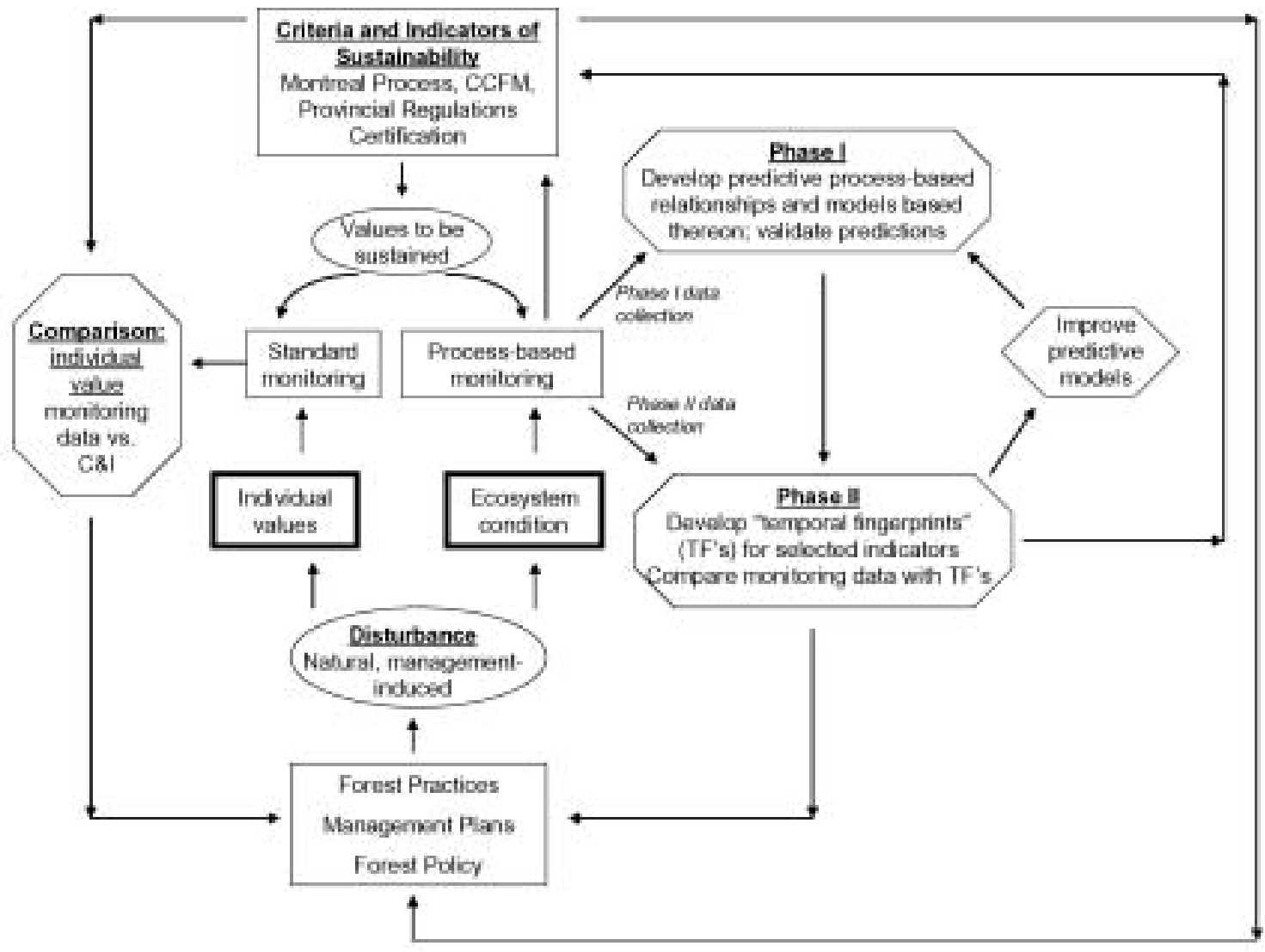

Fig. 4. Process-based "Smart", ecosystem-level monitoring contrasted with conventional monitoring. The latter compares audits/monitoring data that describe present conditions with selected indicators of sustainability. Phase I of PBMsmart monitoring also collects data that describe present conditions but in a manner that allows the development of causal and predictive process-based relationships between measurable ecosystem attributes (indicators) and values of interest. These relationships are used in Phase II to develop "temporal fingerprints" of expected change in the values. Monitoring data are subsequently collected to compare with these temporal patterns of indicator values. PBM"Smart" monitoring is what is envisaged in Adaptive Management, but not what occurs in many conventional audits. See text for further explanation. Note that the ecosystem management models used in PBM"smart" monitoring systems can also be used to assess the utility of particular indicators, and suggest alternatives (e.g. Morris et al. 1997, Seely and Welham 2006).

tem that is developed can also be used in general management planning (see examples below), giving further "value added" to the "upfront" investment in PBM.

After an acceptable level of reliability of the PBM system has been established, the sustainability of a proposed stand and landscape management strategy is assessed in Phase II. The assessment is conducted within the context of risks such as fire, insect outbreaks, wind damage and climate change, all of which should be addressable by the models used in PBM. Once the monitoring support system has been established and verified, ongoing monitoring is reduced to periodic lower intensity, targeted data collection that provides a check on the efficacy of the management system (are the monitored ecosystem conditions consistent with the model-established temporal fingerprints of sustainability in the ecosystem being monitored), and to steadily increase the data upon which the predictive model(s) is/are based. Alternative management regimes can then be considered to assess their relative sustainability in a series of scenario and value trade-off analyses (e.g., Morris et al. 1997, Wei et al. 2003).

Most of the components of a suitable decision support system for PBM already exist and have been successfully combined into cross-scale, multi-value meta-models in a variety of applications across Canada. Analyses of this type have been underway for several years in B.C. (e.g., Seely et al. 2004, Welham et al. 2004, Seely 2005a). This work demonstrates that not only can such an approach be practical and operational for the assessment of the relative sustainability of different management strategies: it is also useful for testing the efficacy of existing indicators and suggesting new indicators that can provide practical and affordable monitoring (Seely 2005a, b; Seely and Welham 2006). Similar multi-scale, multivalue decision support tools based on other models and suitable for application in PBM monitoring systems are available. 

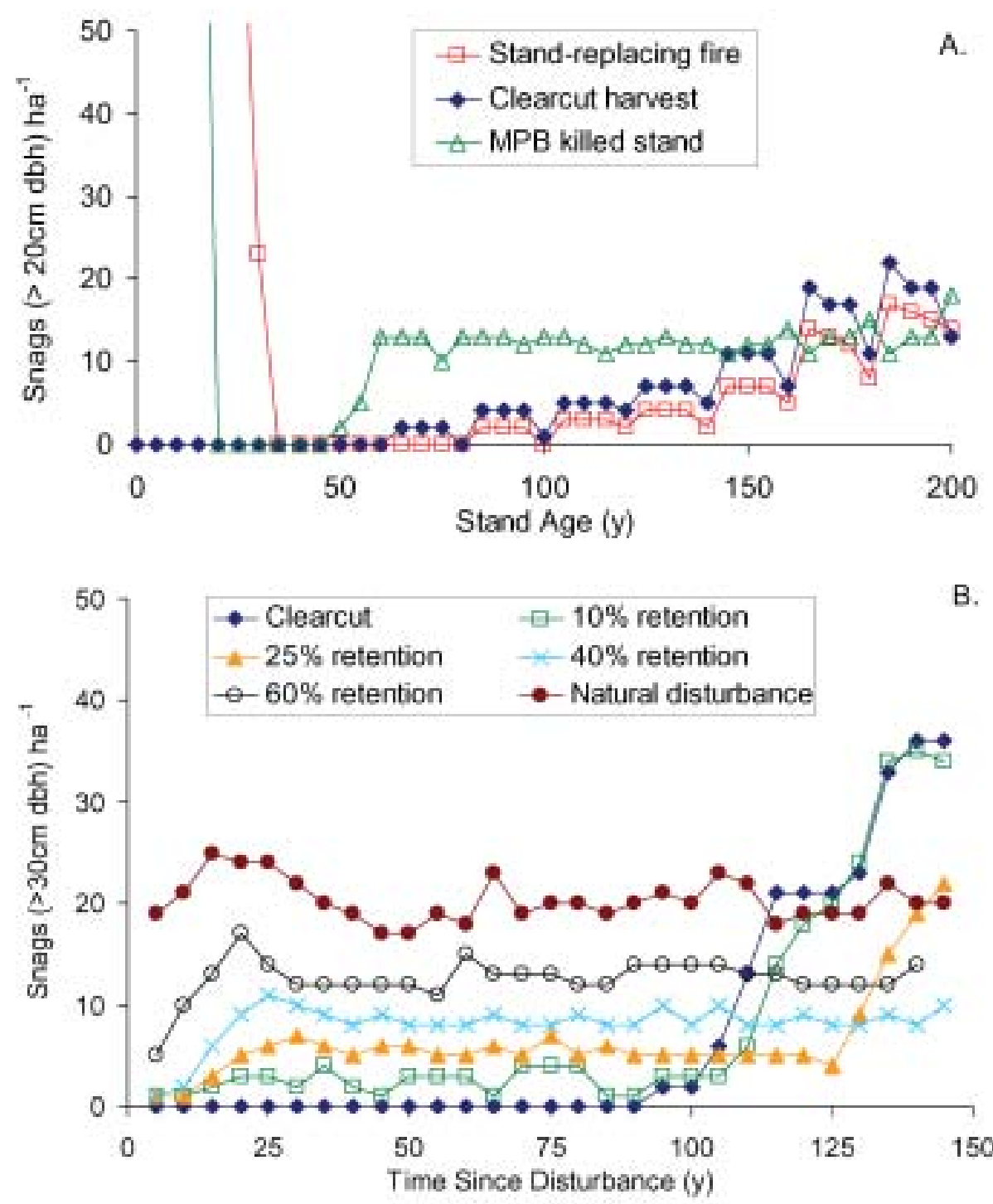

Fig. 5. An example of the projected temporal patterns of the population of large-diameter snags in two ecosystem types within British Columbia: A) an even-aged, lodgepole-pine-dominated stand subjected to a stand replacing fire, mountain pine beetle attack (unsalvaged), and clearcut harvesting (adapted from Seely 2005b); B) an uneven aged coastal western hemlock/western redcedar stand type subjected to endemic "gap-dynamic" disturbance agents ["natural disturbance"] compared with stands harvested with varying levels of dispersed retention (0-60\%) (adapted from Welham et al. 2004). These projections were intended to be used as a basis to guide future monitoring endeavors.

An example of the use of a stand-level, process-based, ecosystem-level model to project temporal fingerprints (in this case, trends in large-diameter snags - an indicator of habitat quality for cavity nesting birds and other secondary cavity-using groups) is illustrated in Fig. 5. Fig. 5A shows the expected long-term trends in snag density for mature lodgepole-pine-dominated stands in interior BC subject to two types of stand-replacing natural disturbances (fire and Mountain Pine Beetle attack), and clearcut harvesting. Substantial temporal variation in snag density associated with both of the natural disturbance agents illustrates the importance of using temporal patterns of change as a context for monitoring. Fig. 5B illustrates similar projections of snag density but for an uneven-aged western hemlock / western red- cedar stand type in coastal BC. In this case, trends in snag density were compared for endemic "gap-dynamics" natural disturbance agents and a series of partial harvesting strategies with varying levels of retention. Again, not only does the model establish a context for monitoring, it also establishes indicator targets and thresholds by comparing alternative silviculture systems against natural disturbance baselines. Such stand-level ecosystem management modeling can be scaled up to timber supply areas or larger units by linking the models with large landscape models of various types (e.g., Seely et al. 2004).

Process-based models are also being used at the landscape scale for the simulation of natural disturbance. For example, new timber management guidelines are being developed in Ontario to deal with landscape-level planning, and as part of 
the development process alternative policy options are simulated using the Patchworks harvest scheduling program (www.spatial.ca/products). The projected future forest conditions are then evaluated in terms of biodiversity conservation using multiple-scale, spatial habitat models for a focal species group. A similar approach was used for development of forest management plans by Louisiana Pacific in Manitoba (Rempel et al. 2006). Harvest projection models, however, are generally empirical in nature and not process-based, so to place the evaluation of policy options in the context of natural processes, a process-based natural disturbance model, BFOLDS, was used to generate a simulated range of natural variation for future landscape patterns (Perera et al. 2004).

The effects of policy options on future composition, pattern, and habitat suitability were thus examined using a forward- rather than backward-looking approach. As work begins on the consequences of climate change, weather parameters in BFOLDS will be adjusted to evaluate expected consequences on future forested conditions. Although stand development attributes (e.g., snag density and crown closure) were initially modeled using empirical methods, future iterations of the work in Ontario will utilize the hybrid processbased model FORECAST (Kimmins et al. 1999).

A key feature of any adaptive management program is the feedback between monitoring results and management. Because the proposed framework for PBM is based on a decision support approach that is increasingly being used in forest management planning, the costs will not be incremental. The monitoring support system will simply be an extension of the system of stand and landscape management tools that companies and government agencies are already using in resource management planning and public review processes. To assist the latter, the output from such a system should be linked with advanced visualization systems - a trend that is being applied increasingly more often in forestry (e.g., Kimmins 2001, Sheppard and Harshaw 2001).

\section{Conclusions}

Sustainability is a relative concept whose interpretation depends on the temporal and spatial scales over which it is evaluated. On one hand, it can be considered in terms of snapshots of individual ecosystem values and environmental services. Alternatively, it can be approached as a complex, dynamic system, the overall character and function of which at the landscape scale may be relatively constant, but with individual characteristics and sub-areas (stand-level ecosystems) that vary significantly over time. The latter approach makes more sense ecologically and practically. Long-term sustainability of many temperate and most northern forest types requires periodic disturbance, and sustainability therefore has little to do with constancy and lack of change.

Assessment of sustainability through monitoring must address this spatial and temporal complexity in terms of the combinations of frequency and severity of disturbance that are in balance with the rate of post-disturbance ecosystem development. This renders static lists of indicators relatively ineffective as the basis for monitoring sustainability. A more dynamic approach, one that is embodied in the concept of adaptive management, involves the creation of temporal fingerprints of sustainable change in ecosystem form and function against which to compare targeted monitoring.
Traditionally, forest monitoring has produced large quantities of data. These data are usually poorly synthesized and evaluated because government regulatory agencies and forest companies generally lack the human resources needed for processing and interpretation. This has limited the value of traditional monitoring data to forest managers and policymakers. The synthesis of monitoring data within appropriate models can greatly increase the accessibility to decision-makers of this important component of sustainable and adaptive management. The use of models can make a useful contribution to the design of monitoring activities by identifying critical data needs and defining the scales and frequencies of data collection. They are an essential component of a PBM monitoring strategy.

PBM-monitoring that is both economically and humanresource efficient—should replace conventional monitoring for sustainability and stewardship assessment in forestry. This involves applied research to develop predictive monitoring decision support systems, the use of these systems to create ecosystem and management-specific temporal fingerprints, and targeted monitoring to assess the consistency of ecosystem change to the pattern defined in a sustainable "fingerprint." PBM will not and should not replace all other forms of monitoring, though we argue that it is a necessity for most sustainability monitoring in forestry.

\section{References}

Aber, J.D., S.V. Ollinger, C.A. Federer, P.B. Reich, M.L. Goulden, D.W. Kicklighter, J.M. Melillo and R.G. Lathrop, Jr. 1995. Predicting the effects of climate change on water yield and forest production in the northeastern United States. Clim. Res. 5: 207-222.

Annan, K. 2000. Sustaining our future. In We the Peoples. The Role of the United Nations in the 21st Century. pp. 54-65. United Nations Department of Public Information, New York, NY.

Attiwill, P.M. 1994. The disturbance of forest ecosystems: the ecological basis for conservation management. For. Ecol. Manage. 63(2-3): 247-300.

Bhatti, J.S., N.W. Foster, T. Oja, M.H. Moayeri and P.A. Arp. 1998. Modeling potentially sustainable biomass productivity in jack pine stands. Can. J. Soil Sci. 78: 105-1134.

Bi, J., J.A. Blanco , B. Seely , J. P. Kimmins, Y. Ding, and C. Welham. 2006. Yield decline in Chinese-fir plantations: A simulation investigation with implications for model complexity. Can. J. For. Res. (In review.)

Burton, P.J., C. Messier, D.W. Smith and W.L. Adamowicz, (eds.). 2003. Towards Sustainable Management of the Boreal Forest. NRC Research Press, Ottawa, ON. 1039 p.

Bruntland, G.H. 1987. Our Common Future. The World Commission on Environment and Development, Oxford University Press, Oxford, UK. 400 p.

Canadian Council of Forest Ministers (CCFM). 1997. Criteria and indicators of sustainable forest management in Canada. Technical Report. Ottawa, ON. 145 p.

Cashore, B., G.C. van Kooten, I. Vertinsky, G. Auld and J. Affolderback. 2005. Private or self-regulation? A comparative study of forest certification choices in Canada, the United States and Germany. Forest Pol. Econ. 7: 53-69.

Duchesneau, R. 2005. A compendium of sustainable forest management network computer simulation modeling. Sustainable Forest Management Network, Edmonton, AB. 56 p.

Franklin, J.F., D.R. Berg, D.A. Thornburgh and J.C. Tappeiner 1997. Alternative silvicultural approaches to timber harvesting: variable retention harvest systems. In K.A. Kohm and J.F. Franklin (eds.). Creating a Forestry for the 21st Century: The Science of Ecosystem Management. pp. 111-139. Island Press, Washington, DC. 
Franklin, J.F., T.A. Spies, R. Van Pelt, A.B. Carey, D.A. Thornburgh, D.R. Berg, D.B. Lindenmayer, M.E. Harmon, W.S. Keeton, D.C. Shaw, K. Bible and J. Chen. 2002. Disturbances and structural development of natural forest ecosystems with silvicultural implications, using Douglas-fir forests as an example. For. Ecol. Manage. 155: 399-423.

Guisan, A. and N.E. Zimmermann. 2000. Predictive habitat distribution models in ecology. Ecol. Model. 135: 147-186.

Holthausen, R., R. Czaplewski, D. DeLorenzo, G. Hayward, W.B. Kessler, P. Manley, K.S. McKelvey, D.S. Powell, L. Ruggiero, M.K. Schwartz, B. Van Horne, and C.D. Vojta,. 2005. Strategies for monitoring terrestrial animals and habitats. Gen. Tech. Rep. RMRSGTR-161. U.S. Dept. Agri., Forest Service, Rocky Mountain Research Station, Fort Collins, CO. $34 \mathrm{p}$

Johnsen, K., L. Samuelson, R. Teskey, S. McNulty and T. Fox. 2001. Process models as tools in forestry research and management. For. Sci. 47(1): 2-8.

Johnson, D.W. 1994. Reasons for concern over impacts of harvesting. In W.J. Dyck, D.W. Cole and N.B. Comerford (eds.). Impacts of Forest Harvesting on Long-term site Productivity. pp. 1-12. Chapman and Hall, London, UK.

Kimmins, J.P. 1974. Sustained yield, timber mining, and the concept of ecological rotation: a British Columbian view. For. Chron. 50(2): 27-31.

Kimmins, J.P. 1977. Evaluation of the consequences for future tree productivity of the loss of nutrients in whole-tree harvesting. For. Ecol. Manage. 1: 169-183.

Kimmins, J.P. 1990a. Monitoring the condition of the Canadian forest environment: the relevance of the concept of "ecological indicators". Environ. Monit. Assess. 15: 231-240.

Kimmins, J.P. 1990b. Workgroup issue paper: Indicators and assessments of the state of forests. Environ. Monit. Assess. 15: 297-299.

Kimmins, J.P. 1990c. Modelling the sustainability of forest production and yield for a changing and uncertain future. For. Chron. 66(6): 271-280.

Kimmins, J.P. 1996. The health and integrity of forest ecosystems: are they threatened by forestry? Ecosys. Health. 2(1): 5-18.

Kimmins, J.P. 1997. Biodiversity and its relationship to ecosystem health and integrity. For. Chron. 73(2): 229-232.

Kimmins, J.P. 1999. Biodiversity, Beauty and the "Beast": Are beautiful forests sustainable, are sustainable forests beautiful, and is "small" always ecologically desirable? For. Chron. 75(6): 955-960.

Kimmins, J.P. 2001. Visible and non-visible indicators of forest sustainability: beauty, beholders and belief systems. In S.R.J. Sheppard and H.W. Harshaw (eds.). Forests and Landscapes: Linking Ecology, Sustainability and Aesthetics. IUFRO Research Series No. 6. pp. 43-56. CABI Publishing, Wallingford, UK.

Kimmins, J.P. 2002a. Future shock in forestry. Where have we come from; where are we going; is there a "right way" to manage forests? Lessons from Thoreau, Leopold, Toffler, Botkin and Nature. For Chron. 78(2): 263-271.

Kimmins, H. 2002b. Ecosystem monitoring. In A.H. El-Shaarawi and W.W. Piegorsch (eds.). Encyclopedia of Environmetrics, Volume 2. pp. 618-622. Wiley, Chichester, U.K.

Kimmins, J.P. 2004. Emulation of natural forest disturbance. What does this mean? In A.H. Perera, L.J. Buse and M.G. Weber (eds.). Emulating Natural Forest Landscape Disturbances: Concepts and Application. pp. 8-28. Columbia University Press, New York, N.Y. 315 p.

Kimmins, J. P. 2005. Forest Ecology. The Ecological Stage, the Ecological Play, and the Ecological Actors in Forest Ecosystems. In S. B. Watts and L. Tolland (eds.). Forestry Handbook for British Columbia. pp. 433-471. Faculty of Forestry, University of British Columbia. Vancouver, BC.

Kimmins, J.P. 2007a. Sustainability: a focus on forests and forestry. In P.N. Nemetz (ed.). Sustainable Resource Management. pp. 254-283. Edw. Elgar Publ., Camberley, UK.
Kimmins, J. P. 2007b. Forest Ecosystem Management: Miracle or Mirage? In T.B. Harrington and G.E .Nicholas (tech. eds.). Managing for Wildlife Habitat in West-side Production Forests. pp. 19-31. USDA Forest Service, PNW Research Station, General Technical Report PNW-GTR-695.

Kimmins, J.P., D. Mailly and B. Seely. 1999. Modelling forest ecosystem net primary production: the hybrid simulation approach used in FORECAST. Ecol. Model. 122: 195-224.

Kimmins, J.P., C. Welham, B. Seely, M. Meitner, R. Rempel and T. Sullivan. 2005. Science in Forestry: Why does it sometimes disappoint or even fail us? For. Chron. 85(5): 723-734.

Kneeshaw, D.D., A. Leduc, P. Drapeau, S. Gauthier, D. Pare, R. Carnigan, R. Doucet, L. Bouthillier and C. Messier. 2000. Development of integrated ecological standards of sustainable forest management at an operational scale. For. Chron. 76(3): 481-493.

Korzukhin, M.D., M.T. Ter-Mikaelian and R.G. Wagner. 1996. Process versus empirical models: which approach for forest ecosystem management? Can. J. For. Res. 26: 879-887.

Landsberg, J.J. 2003. Modelling forest ecosystems: state of the art, challenges, and future directions. Can. J. For. Res. 33: 385-397.

Landsberg, J.J. and R.H. Waring. 1997. A generalised model of forest productivity using simplified concepts of radiation-use efficiency, carbon balance and partitioning. For. Ecol. Manage. 95: 209-228.

Lindenmayer, D.B. and J.F. Franklin (eds.) 2003. Towards Forest Sustainability. CSIRO, Collingwood, Victoria, Australia. 231 p.

Messier, C., M.J. Fortin, F. Schmiegelow, F. Doyon, S.G. Cumming, J.P. Kimmins, B. Seely, C. Welham and J. Nelson. 2003. Modelling tools to assess the sustainability of forest management scenarios. In P.J. Burton, C. Messier, D.W. Smith and W.L. Adamowicz (eds.). Towards Sustainable Management of the Boreal Forest. pp. 531-580. NRC Research Press, Ottawa, ON. 1039 p.

Messier, C. and D.D. Kneeshaw. 1999. Thinking and acting differently for sustainable management of the boreal forest. For. Chron. 75(6): 929-938.

Morris, D.M., J.P. Kimmins and D.R. Duckart. 1997. The use of soil organic matter as a criterion of the relative sustainability of forest management alternatives: a modelling approach using FORECAST. For. Ecol. Manage. 94: 61-78.

Mulder, B.S., B.R. Noon, T.A. Spies, M.G. Raphael, C.J. Palmer, A.R. Olsen, G.H. Reeves and H.H. Welsh.1999. The strategy and design of the effectiveness monitoring program for the Northwest Forest Plan. Gen. Tech. Rep. PNW-GTR-437. U.S. Department of Agriculture, Forest Service, Pacific Northwest Research Station, Portland, OR. $138 \mathrm{p}$.

Nemetz, P.N. (ed.). 2004. Sustainable Resource Management: Reality or Illusion? Journal of Business Administration and Policy Analysis. Faculty of Commerce and Business Administration, The University of British Columbia, Vancouver, BC. 482 p.

Nisbet, T., J. Dutch and A. Moffat. 1997. Whole-tree harvesting: A guide to good practice. Forestry Practice Guide. Forestry Commission, Edinburgh, UK. 12 p.

Oliver, C.D., J.P. Kimmins, H.W. Harshaw and S.R.J. Sheppard. 2000. Criteria and indicators of sustainable forestry: A system approach. In S.R.J. Sheppard and H.W. Harshaw (eds.). Forest and Landscapes. Linking Ecology, Sustainability and Aesthetics. IUFRO Research Series, No. 6. pp. 73-93. CABI Publishing, Wallingford, UK. Olsson, B.A., H. Staaf, H. Lundkvist, J. Bengston and K. Rosen. 1996. Carbon and nitrogen in coniferous forest soils after clear-felling and harvests of different intensity. For. Ecol. Manage. 82: 19-32.

Peng, C., J. Liu, Q. Dang, M.J. Apps, H. Jiang. 2002. TRIPLEX: a generic hybrid model for predicting forest growth and carbon and nitrogen dynamics. Ecol. Model. 153: 109-130.

Perera, A.H., L.J. Buse and M.G. Weber (eds.). 2004. Emulating Natural Forest Landscape Disturbances: Concepts and Applications. Columbia University Press, New York, NY. 315 p.

Powers, R.F., F.G. Sanchez, D.A. Scott and D. Page-Dumroese. 2004. The North American long-term soil productivity experiment: coast- 
to-coast findings from the first decade. In W.D. Sheppard and L.G. Eskew (compilers). Silviculture in special places: proceedings of the 2003 National Silviculture Workshop. September 8-11, 2003, Granby, CO. Proceedings RMRS-P-34. pp. 191-206. U.S. Department of Agriculture, Forest Service, Rocky Mountain Research Station, Fort Collins, CO. 255 p.

Rauscher, H.M. 1999. Ecosystem management decision support for federal forests in the United States: A review. For. Ecol. Manage. 114: 173-197.

Rempel, R.S., D.W. Andison and S.J. Hannon. 2004. Guiding principles for developing an indicator and monitoring framework. For. Chron. 80(11): 82-90.

Rempel, R.S., M. Donnelly, L. Van Damme, M. Gluck, R. Kushneriuk and T. Moore. 2006. Spatial landscape assessments models: a meta-modelling framework for biodiversity conservation planning. In R. Lafortezza and G. Sanesi (eds.). Patterns and Processes in Forest Landscapes, Consequences of Human Management. Proceedings of the 4th Meeting of IUFRO Working Party 8.01.03. September 26-29, 2006. pp. 161-167. Locorotondo, Bari, Italy.

Royo, A.A. and Carson, W.P. 2006. On the formation of dense understory layers in forest worldwide: consequences and implications for forest dynamics, biodiversity, and succession. Can. J. For. Res. 36: 1345-1362.

Salim, E. and O. Ullsten. 1999. Our Forests, Our Future. Report of the World Commission on Forests and Sustainable Development. Cambridge University Press, Cambridge, UK. 205 p.

Schoenholtz, S.H., H. van Miegroet and J.A. Burger. 2000. A review of chemical and physical properties as indicators of forest soil quality: challenges and opportunities. For. Ecol. Manage. 138: 335-356.

Seely, B. 2005a. Development of indicator 2-1 of the SFM Framework: Establishing thresholds, evaluating current practices, and refining monitoring strategies. Unpublished report for Canadian Forest Products Ltd., Forest Nelson Division. Department of Forest Sciences, University of British Columbia, Vancouver, B.C. Seely, B. 2005b. Development of stand attribute curves for the Vanderhoof IFPA certification project. Unpublished report for CANFOR Ltd., by FORRx Consulting Inc., Belcarra, BC.

Seely, B., J.P. Kimmins, C. Welham and K. Scoullar. 1999. Defining stand-level sustainability, exploring stand-level stewardship. J. Forest. 97(6): 4-10.
Seely, B., J. Nelson, R. Wells, B. Peter, M. Meitner, A. Anderson, H. Harshaw, S. Sheppard, F.L. Bunnell, H. Kimmins and D. Harrison. 2004. The application of a hierarchical, decision-support system to evaluate multi-objective forest management strategies: a case study in northeastern British Columbia, Canada. For. Ecol. Manage. 199(2-3): 283-305.

Seely, B. and C. Welham. 2006. Towards the application of SOM as a measure of ecosystem productivity in the Quesnel Forest District: Deriving thresholds, determining effective sampling regimes, and evaluating practices. FSP Project Y061143. Unpublished report for Canadian Forest Products Ltd., Quesnel Division. FORRx Consulting Inc., Belcarra, BC.

Sheppard, S.R.J. and H.W. Harshaw (eds.). 2001. Forests and Landscapes: Linking Ecology, Sustainability and Aesthetics. IUFRO Research Series, No. 6. CABI Publishing, Wallingford, UK. 294 p.

Thomas, J.W. 1995. The Forest Service Program for Forest and Rangeland Resources: A long-term strategic plan. Draft 1995. RPA Program, USDA Forest Service, Washington, DC.

United Nations Conference on Environment and Development (UNCED). 1992. Agenda 21: the Rio Declaration on Environment and Development, and the Statement of principles for the Sustainable Management of Forests. June 3-14, 2003, Rio de Janeiro, Brazil.

Walters, C.J. 1986. Adaptive Management of Renewable Resources. Macmillan, New York, NY. 374 p.

Wei, X., J.P. Kimmins and G. Zhou. 2003. Disturbances and the sustainability of long-term site productivity in lodgepole pine forests in the central interior of British Columbia - an ecosystem modeling approach. Ecol. Model. 164(2-3): 239-256.

Welham, C., B. Seely and G.Q. Bull. 2004. Establishing targets and trajectories for selected ecological indicators of sustainable forest management on Tree Farm Licence 57. Research report. Department of Forest Sciences, University of British Columbia, Vancouver, BC. 24 p. Westoby, J.C. 1987. The Purpose of Forests: Follies of Development. Blackwell Publishing. New York, NY. 343 pp.

Zeide, B. 2003. The U-approach to modeling. Can. J. For. Res. 33(3): 480-489. 